\title{
Öryggi sjúklinga og flækjustig nútíma heilbrigðispjónustu
}

Pað eru tískustraumar í heilbrigðispjónustu eins og öðru. Nú er tískan sú að setja sjúklinginn í öndvegi og veita pjónustu sem tekur mið af pörfum einstaklingsins og aðstandenda hans. Рað felur meðal annars í sér að sýna virðingu og virkja sjúklinginn í eigin meðferð á pann hátt sem hefur virði fyrir hann. Hversu vel gengur petta hjá okkur? Uppfyllum við pau 8 pjónustuáheit sem Picker Institute hefur skilgreint sem undirstöðu sjúklingamiðaðrar pjónustu? Hvenær spyrjum við sjúklinginn „hvað skiptir pig máli"?

Á tímum velferðar og framfara í læknavísindum og með petta í huga, er nokkuð ljóst að við höfum óafvitandi skapað okkur fjölda nýrra verkefna sem krefjast meiri sampættingar og heildrænni hugsunar en við höfum áður pekkt í heilbrigðispjónustu. Eftir pví sem samfélag okkar próast og vegnar betur, eykst heilbrigði og langlífi. Jafnframt lengist líf fólks með fleiri og flóknari sjúkdóma sem krefst meiri sérhæfni og flóknari meðferða. Ört vaxandi hópur fólks lifir ekki aðeins lengur með sjúkdómana sína, heldur hefur væntingar um árangur og gerir kröfur um gæði og öryggi. Við sem veitum heilbrigðispjónustu fikrum okkur sífellt lengra í pví að praktísera á mörkum pess sem er lífeðlisfræðilega mögulegt. Pótt um flest gangi pað vel og árangur íslenska heilbrigðiskerfisins sé um margt góður, höfum við ekki náð að halda í við pessa próun hvað varðar pað að tryggja gæði og öryggi í pjónustunni.

Vinnuskipulag lækna er til marks um petta, enda heilt yfir að mestu leyti eins og fyrir 30 árum, sérstaklega að sumarlagi pegar Ísland lokar og fer í frí, í júlí. Við höfum til áratuga lokað legudeildum og sameinað starfsemi að sumarlagi, til að spara aura og hleypa fólki í frí. Við látum okkur hafa pað að vera (meira) undirmönnuð petta tímabil, hlaupum (enn) hraðar. Einnig ráðum við inn afleysingafólk, læknanemana. Gott fólk og samviskusamt, framtíð okkar og vonarstjörnur í faginu, en eigi að síður nemar, með peim takmörkunum og hættum sem peim fylgja. Okkur ber skylda til að tryggja pessu ágæta fólki góða byrjun á ferlinum. Pau eiga pað skilið. Pess í stað hendum við peim út í djúpu laugina, hlöðum á pau ábyrgð sem pau eru ekki tilbúin fyrir og setjum pau í verkefni sem pau hafa ekki forsendur til að ráða við. Óreynt starfsfólk í framlínu er sá páttur í starfseminni sem hefur í rannsóknum á alvarlegum sjúklingaatvikum sýnt sig að vera einna oftast rót eða meðvirkandi orsök atviksins. Einnig sést iðulega í sömu rannsóknum að handleiðsla hefur brugðist og að skipulag starfseminnar tekur ekki mið af aðstæðum. Á sama tíma og við ráðum inn nemana í stórum stíl, útskrifast tugir íslenskra lækna úr erlendum háskólum. Hvað verður um petta fólk? Hví getum við ekki ráðið pað? Gætum við ekki gert betur í að rækta tengslin við pessa kollega okkar?

Petta galna vinnufyrirkomulag á orlofstíma og reyndar á öðrum tímum líka, er barn síns tíma og mætir ekki pörfum sjúklingsins í dag. Pað fyrirfinnst hvergi í peim löndum sem við berum okkur saman við. Рað hlýtur að teljast ófullnægjandi á vorum tímum að stoppa í götin á pennan hátt, að telja bara hausa en ekki hæfni.

Pann 2. mars síðastliðinn sendi landlæknir bréf til forsvarsmanna heilbrigðisstofnana, par sem hann áréttaði að samkvæmt 11. grein laga nr. 34/2012 um heilbrigðisstarfsmenn, sé landlækni heimilt ef nauðsyn krefur, að veita nemum sem lokið hafa 4. ári í læknisfræði tímabundið leyfi til að sinna tilgreindum læknisstörfum. Í bréfinu kemur hins vegar fram að ásókn stjórnenda lækninga á heilbrigðisstofnunum í afgreiðslu leyfanna sé slík að hún gefi glöggt til kynna að sjálfsagt pyki að nemar séu nýttir til að leysa afleysinga- og mönnunarvanda stofnana. Einnig beri á pví að pessar umsóknir séu ekki nógu vandaðar. Oft komi í ljós að neminn hafi pegar hafið störf pegar umsókn berst, sem er brot á lögum. Landlæknir segist eftirleiðis munu skoða umsóknir með gagnrýnum hætti og beita sér fyrir pví að pessu lagaákvæði verði breytt.

petta er mjög áhugavert og auðvitað hárrétt hjá landlækni. Við sem vinnum við rannsóknir á alvarlegum sjúklingaatvikum pekkjum petta úr eigin starfsemi og höfum sjálf upplýst landlækni og stjórnendur innanhúss. Pví geta menn ekki lengur látið sem ekkert sé. Nauðsynlegt er að gera pá sjálfsögðu kröfu til starfseminnar að hún sé skipulögð pannig að hún mæti pörfum sjúklinganna og tryggi sem best öryggi peirra. Stjórnendur lækninga purfa að leggja sig fram til að tryggja að svo sé, pó áskoranir séu par vissulega margar. Með pessu hefur fráfarandi landlæknir gefið tóninn. Fróðlegt verður að sjá hvernig nýr landlæknir hyggst fylgja pessu eftir. 